\title{
Maritime Security Challenges in the Indian Ocean: Special Reference to Sri Lanka
}

\author{
P.K.B. Isuru Premarathna \\ University of Kelaniya, Sri Lanka
}

\begin{abstract}
Maritime security is an umbrella term informed by security agendas to classify issues in the maritime domain that are often related to national security. Maritime security is one of the latest Buzzwords of International Relations. Major actors have started to include maritime security in their mandate or reframed their work in such terms. Non-traditional security threats are treated as a novel trend in the concept of security. The Indian Ocean Region has emerged as the world's major energy and trade routes. Sri Lanka's location is also strategically very important. The Indian Ocean region faces many traditional and non-traditional safety and security challenges. Such as piracy, armed robberies at sea, terrorism, human trafficking, irregular movement of persons, drug trafficking, illicit trafficking in wildlife, trafficking of weapons, IUU fishing, climate change, etc. The main objective of this research is to identify and study the challenges of maritime security conservation in the Indian Ocean as well as in contemporary Sri Lanka. The research problem is, how are the Indian Ocean maritime security issues in the Indian Ocean as well as in contemporary Sri Lanka. The Methodology that followed for this study is qualitative in nature while using both primary and secondary data. To collect primary data, a sample of 30 people has been used in the fields of government, academic, military, and other professionals. According to the study, as a challenges pose a threat to Indian ocean security today, increasing militarisation of Indian ocean's strategic chokepoints, vast regions of the Indian ocean remain 'unpoliced', particularly the central Indian ocean, maritime awareness (MDA) is lax, increasing naval competition between some littoral states and major maritime users and ensuring freedom of navigation along the Indian ocean's sea lanes of communication, whist closing these lines to illegal actors. Maritime terrorism, climate change, and environmental degradation, the unregulated exploitation of marine resources, illegal trafficking (arms, drugs) also the challenges Sri Lanka is facing today. According to the research, non-traditional maritime security challenges exist mainly in the contemporary Indian Ocean region and Sri Lanka. Moreover, currently in this region in the evaluation of its impact on political, economic, military, societal, and environmental security, the most alarming impacts can be identified on political security and environmental security.
\end{abstract}

Keywords - Maritime security, Indian Ocean Region, Sri Lanka, non-traditional maritime security

\section{INTRODUCTION}

\subsection{Background of the study}

The research aims to focus on maritime security and 1 maritime security challenges in the contemporary challenges in the Indian Ocean region. Maritime security and non-traditional security issues in Sri Lanka and the Indian
Ocean region see as a new trend in the field of international relations. The Indian Ocean region has emerged as one of the world's major energy and trade routes. Sri Lanka and the Indian Ocean region are strategically important. It is important to identify and study the maritime security challenges and issues in Sri Lanka and the Indian Ocean region at present. The main reason for conducting this research is the strategic problems and challenges that exist in the region. Also, studies conducted in this regard in the field of research are very rare.

\subsection{Identification of the research problem and Research} questions

The Indian Ocean has also become of substantial interest to major power beyond the region and has increasingly become a theatre in which global geopolitical rivalries play out. This is due to the importance of its maritime trading and communications routes, as well as the rich natural resources of many of its littoral states. The Indian Ocean region is vast in terms of its sheer scope. Also, the Indian Ocean is of paramount importance in the study of maritime security. Currently, there are major issues and challenges related to maritime security. The primaries identifiable are traditional and non-traditional security threats. That is piracy, armed robberies at sea, terrorism, human trafficking, irregular movement of persons, drug trafficking, illicit trafficking in wildlife and so on. The main focus of this research was on the maritime security challenges facing Sri Lanka in the Indian subcontinent. Is to identify. Where the Indian rejoins explores the challenges affecting maritime security, and what are they? Also reflected in the research problem. The primary focus of the research was to identify and explore factors affecting maritime security in Indian Ocean region. In the current context of international relations, special attention is being paid to maritime security issues. The research problem expected to be studied by the research team was to make a qualitative and quantitative analysis of the exiting maritime threats to the contemporary Indian ocean.

Maritime security is a timely research area. Every nation has its national aspirations, national security directly and indirectly on maritime security. But not so for a land lock country. The Indian Ocean has always been a strategically important head among the superpowers. Here it is important to focus on a maritime strategic location and maritime security. Therefore, in this research, the main issues of this research area are to investigate the maritime security in the 
contemporary Indian Ocean and to study the problems that exist there.

\subsection{The objective of the study}

The main objective of this research is to study the contemporary maritime security challenges in the Indian Ocean and the purpose here is to explore a wide range of challenges.

\section{The primary objectives of the research are:}

1. Study of traditional and non-traditional maritime security challenges

2. Identify of the current maritime security challenges

3. Identify of challenges found in Sri Lanka and the Indian Ocean.

\subsection{Research methodology}

\section{- Research design and approach}

The quality research method was used principally for this research. Thirty (30) experts were involved in the research sample. Ethnographic methodology was also used for Specialty research methodology and in-depth interview and research-related observation methodology.

\section{- Methodological Framework (Data Collection Screening / Secondary Sources / Primary Sources / Data Analysis Process)}

The study recognises the importance of experts, researchers and policy makers, suggestions and recommendations as a tool to understand policies and strategies in both countries. The methodology of this empirical study is explained in more detail.

Data sources are at once primary and secondary. Descriptive analysis was used for research purposes. Other than this method of study, a detailed questionnaire was used in the selective sample of the study. For more information about marine safety, structured interviews using a questionnaire guide were also held by respondents in institutions and recognized authorities in Sri Lanka. Some international respondents agreed to reply by voice mail such as Gmail voice chat. Secondary data, such as manuals, journals, publications, websites and online journals were used to collect secondary data.

Barry Buza's safety analysis, Hans Morgenthau's six principles of political realism, the rationalistic approach and the creative approach are the principal theoretical tools used in the study. Apart from them a SWOT analysis was applied to determine positive and negative views of the issues and results of SWOT analysis were used at the end to formulate schemes to act effectively on maritime subjects.

\section{INTRODUCTION (CONCEPTUAL FRAMEWORK)}

\section{1 Security}

1. Defining security
Security has been studied and fought over for as long as there have been human societies. But as the subject of professional academic inquiry security studies is usually thought of as a relatively recent and largely came to prominence after the Second World War. Security studies are understood as one of the most important subfields of academic IR, the other areas usually being defined as international history, international theory, international law, and international political economy and area studies. Traditional security studies reflected an inherent and traditional concern to preserve the status quo inasmuch as the great powers and the majority of academics who worked within them understood security policies as preventing radical and revolutionary change within international society. A key development within the academic mainstream of security studies occurred in 1983 with the publication of the Barry Buzan's book People, States and Fear. Buzan developed a framework in which he argued that the security of human collectivises was affected by factors in five major sectors, each of which had its focal point and way of ordering priorities.

\section{The framework of Barry Buzan}

- Military: concerned with the interplay between the armed offensive and defensive capabilities of states and states' perceptions of each other's intentions.

- Political: focused on the organizational stability of states, systems of government and the ideologies that give them their legitimacy.

- Economics: revolved around access to the resources, finance and markets necessary to sustain acceptable levels of welfare and state power.

- Society: cantered on the sustainability and evolution of traditional patterns of language, culture, and religious and national identity and custom.

- Environmental: concerned with the maintenance of the local and the planetary biosphere as the essential support system on which all other human enterprises depend.

\section{The Concept of Security}

- "Security" is treated as a multi-dimensional term. Interpretation and scope are regarded as extremely vast and diversified.

- Security studies are usually associated with "threat to survival"

- Security means, "the absence of threats", meaning the possibility of being safe from danger or feeling safe.

- Baldwin defines security as "a low probability of damage to acquire values.

- According to Ike Krahmann, at least three distinct meanings of security in terms of their intended outcomes can be conceptually distinguished across levels of analysis and different types of threats.

1. "The first meaning sees security as the absence of a threat. It draws on a preventative concept of security" 
2. "The second meaning of security refers to existing threats that are suspended in the realm of possibility. There seems to be a link to the mechanism of deterrence with this meaning of security. Rather than attempting to deal with, and remove the causes of a threat, security based on deterrence seeks to hold off a threat from becoming an actuality"

3. "The third meaning defines security as the survival of a threat that does become a reality"

- Buzan asserts that "security is about freedom from the threat and the ability of states to maintain independent identity and their functional integrity against forces of change, which they see as hostile while its bottom line is survival".

- Security is generally agreed to be about the feeling of being safe from harm, fear, anxiety, oppression, danger, poverty, defence, protection and preservation of core values and protection from threats to those values.

Barry Buzan's three levels of Analysis of Security

- Individual-level

- National level

- International level

Individual Level- (Human Security)

- Its focus is individuals and its ultimate endpoint is the protection of people from traditional and nontraditional threats.

"Security means protecting fundamental freedoms that are the essence of life. It means protecting people from serious and persistent threats and situations. It means using processes that build on people's strengths and aspirations. It means creating political, social, environmental, economic, military and cultural systems that together give people the building blocks of survival, livelihood and dignity" - The Commission on Human Security (CHS)-

\section{The Seven Dimensions of Human Security}

\section{Economic Security}

- Requires an assured basic income for individuals, mostly from productive and remunerative work or from a publicly financed safety net.

- Poverty, unemployment, indebtedness, lack of income

\section{Food Security}

- All people at all times have both physical and economic access to basic food.

- Hunger, famines and the lack of physical and economic access to basic food.

3. Health Security
- To guarantee minimum protection from diseases and unhealthy daily life.

- Infections and diseases, Inadequate health care, new and recurrent diseases, including epidemics and pandemics, poor nutrition and unsafe environment and unsafe lifestyles

\section{Environmental Security}

- To protect people from the short and long-term ravages of nature, man-made threats in nature, and deterioration of the natural environment

- Lack of water, air pollution and global warming, environmental degradation, natural disasters and resource reduction.

\section{Personal Security}

- This is all about the protection of individuals and people from physical violence either from the state or outside the state.

- It could be from violent individuals, domestic abuse, torture, war, ethnic tension, individuals or gang crime, industrial, workplace, or traffic accidents.

\section{Community Security}

- Community security aims to protect people from the loss of traditional relationships, values and sectarian and ethnic violence.

- Threats to community security are usually from the group, between groups (ethnic violence), from dominant groups (e.g. Indigenous people's vulnerability, ethnic clashes, land and boundary clashes, and intra - religious and inter-religious conflict all of which constitute threats)

\section{Political Security}

- This embraces the guarantee and protection of fundamental human rights of the citizenry. It is concerned with whether people live in a society that honours their basic freedoms.

- Some of threats attached to these are political or state repression, including torture, disappearance, human rights violations, detention and imprisonment.

\section{National Level - (National Security)}

National security is the preservation of independence and sovereignty of a nation-state.

- Harold Brown - defines national security as,

" The ability to preserve the nation's physical integrity and territory; to maintain its economic relations with the rest of the world on reasonable terms; to preserve its nature, institutions and governance from disruption from outside and to control its borders".

- Simply national security means the preservation of physical survival (Israel-Palestine conflict), 
territorial integrity (Kashmir Conflict), and political independence.

Theoretical views on National Security

Old school (Traditional)

- Hans Morgenthau, Laswell, Walter Lippman

- Views national security from a militarist angle with emphasis on military response and management of threat

- National security as the pursuit of psychological and physical safety, which is largely the responsibility of the national governments

- To prevent direct threat primarily from abroad endangering the survival of these regimes, their citizenry, or their ways of life

The new school (Contemporary)

- National security move beyond the military realm to include non-military factors.

- Old school conception of security cannot capture modern-day security threats like hunger, unemployment, poverty, environmental humiliation and so on.

- National security which is concerned not only with military threats, but with other problems that threaten directly to degrade the quality of life of a national community

Factors affecting the National Security

- Lack of military power and military technologies

- Conflicting political ideologies

- Actions of different civil and political organizations and pressure groups

- Involvement of external great powers

- Drug usage

\section{International Level - (International Security)}

- International security is described as the efforts and measures taken by nations, regional and international organizations to ensure mutual survival and safety through the use of diplomacy and military actions.

- United Nations Development Program (UNDP) Report of 1994 defines international security as freedom from fear and freedom from want; it can be assured from two points of views.

- First, is the safety of the vulnerable people and groups in numerous parts of the world from violent conflicts caused by interstate and intrastate crises and war.

- The second view is the safety of the people from poverty, hunger, unemployment and other kinds of social, economic and political deprivations.

- International security actors have been protracted from individuals, groups, nations, governmental and non-governmental organizations. International organizations like the United Nations and other regional organizations.

Threats to International Security

- Usage of nuclear weapons

- Usage of biological and chemical weapons

- Warlike situations

- Security of developing nations

Measures of mitigating the threats to International Security

- Broaden the role of the United Nations

- Agreements and strict limitations to avoid nuclear warfare

- Disarmament and arms control

- Regional integration

- Nonalignment

- Peaceful co-existence

Two Schools of Thoughts on the Concept of "Security"

Concepts of security

- Traditional security

- non- traditional security

01. Traditional security

Traditional School of Thought

- The Traditional School of Thought favours the maintenance of the Cold War conception of security.

- They define security in this sense to mean safety from danger and external attack or infiltration.

- The traditional security paradigm is a realist construct of security in which the referent object is the state.

- It associates security with peace and prevention of conflict through military means.

- In this view, Walt defines security as a study of threat, use, and control of military force.

- This school of thought is strongly tied to the military and It explores the situations that make use of force more likely, the ways the use of force affects individuals, states, societies and the specific policies.

\section{Non-traditional security}

Non - traditional School of Thought

- This school attempts to widen and deepen the definition of security.

- It argues that other issues like environmental, political, economic, and social threats endanger the lives and properties of individuals rather than the concentration on the survival of the state.

- It does imply that a predominantly military definition does not appreciate it.

- The greatest threat to state survival may not be military, but environmental, health, political, social and economic. 


\section{2 Maritime security and maritime law (Theoretical framework)}

Marine security is a general term used to classify marine matters that are often related to national security, the marine environment, economic development and human security. This includes the world's oceans, but also regional seas, territorial waters, rivers and ports. The theoretical concept of maritime security has evolved from a narrow perspective of projecting domestic naval power to a buzzword that incorporates many interconnected sub-domains. The definition of the term maritime security varies and while no internationally agreed definition exists, the term has frequently been applied to describe both existing, and new regional and international challenges to the maritime sphere. The buzzword enables international stakeholders to discuss these new challenges without having to define all potentially disputed aspects of them.

Some of the practical issues clustered under the term of maritime security include crimes such as piracy, armed robbery at sea, trafficking of people and illicit goods, illegal fishing or marine pollution. Interstate rivalry and violent extremism (maritime terror) are often relevant. This lets in the sea being described a key space for maritime security, including as a "stage for geopolitical power projection, interstate warfare or militarized disputes, as a source of specific threats such as piracy, or as a connector between states that enables various phenomena from colonialism to globalization".

While a concern throughout the history of nation states, maritime security has evolved since the early 2000 s, when particular concerns over terrorist attacks on port facilities sparked interest in security in the maritime field and led to the founding of the International Ship and Port Facility Security Code. Since then, a number of countries and international organizations have outlined marine safety strategies. It is in particular piracy in Southeast Asia, off the coast of Somalia and in West Africa, which has triggered recognition of the damaging effects of maritime insecurities of economic development, human security as well as the surroundings. Maritime safety is often transnational and goes beyond the maritime sphere as such (see liminality). It is characterised as interjurisdictional and/or highly jurisdictional in complexity.

Maritime security is an important concept both internationally and nationally. It is an academic application used to classify issues in national and international security, economic development, human security and maritime region. The theoretical concept of maritime security is shaped by a narrow perspective on naval power projection. Among the major issues filed under maritime security are crimes such as piracy, illegal human trafficking, illegal fishing, smuggling of goods, and maritime pollution. It also plays a key area in international and global terrorism. Historically, maritime security is discussed under various concepts such as the sea, maritime law, power and conflicts. The use of the oceans for various purposes has been the norm since the 17th century, and the concept of a "free sea" in particular has been translated into the United Nations Convention on the Law of the Sea (UNCLOS). According to the concept of "Cannon Short" developed by the Dutchmen Kornelius van Bynkrshoek in determining the maritime boundary of a state, a country has three times the limit of the number of shots fired from the national coast screen and each state can use it freely. In the early part of the 20th century, when some nations expressed a desire to increase national rights. It covered issues such as conservation of fish stocks, control of pollution, and utilization of marine resources. Using the principles of applicable international law to protect natural resources, in 1945 president Truman of the United States included control of all-natural resources that covered the continental shelf. It was followed by other states as well. Between 1946 and 1950, Chile, Peru, and Ecuador extended their fishing borders to 200 nautical miles. Other states increased their legal, maritime boundaries to 12 nautical miles. (Arachchi C.C.H, 2015, UNO, PN .276)

\section{United Nation Convention on the Law of the Sea (UNCLOS)}

1956 the first United Nations conference on the law of the sea is held in Geneva, Switzerland. As a result of the conference in 1958 ,

- September10, 1964, convention on inclusion in the territorial sea and adjacent forces.

- June 10,1964, convention on continental pools.

- September 30, 1962, convention on the deep sea.

- March 20, 1966 convention on the conservation of fisheries and oceans.

Although these were stated in the convention on the United Nations Convention on the Law of the Sea, there were practical problems with the width of the beaches.

United Nation Convention on the Law of the Sea UNCLOSII

The second conference on the law of the sea was held by the united nation in 1960, and no third world countries presenting their views. Only developed countries participated.

United Nation Convention on the Law of the Sea UNCLOSIII

The third United Nations conference on the law of the sea was held in New York. 1967 the issue of seaside diversity raised by Arvid Pardo of Malta is discussed. The convention identifies important approaches and issues, such as delimiting, navigation, the state of the archipelago, the transition conditions, the exclusion of economic zones, marine environment, and areas such as food, scientific research, and conflict resolution have been identified as problems here.

The United Nations has developed a qualitative and quantitative concept of maritime law and security in contemporary spaces. This was an internationally accepted and practiced concept, defined in 1958 at the convention on the sea. Most recently, the UNCLOS III convention, which 
came into force in 1994, included inland and territorial waters, various territorial and judicial powers. Conceptually as well as theoretically, maritime security has evolved from the 1990s to the 2000s. In the year 2000 U.S.S Cole bombing the attacks of September 11, 2001 presented strategies for maritime security. With those attacks came the introduction of ISPS codes from 2002, as well as the qualitative use of physical maritime security and their standards, as well as regulation of the marine industry. Also in contemporary maritime security, the scope extends to concepts such as terrorist threats and maritime security, as well as an interstate military conflict. The 2000s also saw an increase in piracy in maritime security off the Costas of Southeast Asia, coastal Somalia, and West Africa. It also draws attention to policymakers on international trade, economic costs and the physical threats to sailors, maritime security, and the shipping industry. Nowadays, the concepts of maritime security and piracy have been studied and researched by scholars in international relations. The development of regional cooperation policies as a result of piracy, including the regional cooperation agreement (RICAP) on piracy and armed piracy against Asian ships, was launched in 2004, and the international maritime organization Djibouti, which was introduced in 2009. Was an agreement on cooperation between east African and Southeast Asian nations against piracy? The DCOC's supplementary Jeddah amendment in 2017 and subsequent inclusion of illegal, unregistered and unregulated fishing (IEUU) offshore. One of the concepts discussed under humanitarian law is the law of the sea. Maritime law, which was considered purely ritualistic in the 19th century, was no longer, a traditional practice but took on a legal framework due to the 19th century. The main sources on the recognized conventions and declaration made under maritime security and law are,

- The 1856 Paris declaration

- The 1907 Hague convention

- The 1936 Geneva convention protocol

- 1949 Geneva convention II (agreeing on sickness and disaster, armed forces)

\section{Maritime security theoretical approaches}

\section{- Traditional realist approach for maritime security}

In the traditional realist theory of international relations, maritime security is primarily about the meaning of sea power. Realist theory, in more recent terms, defines maritime security as the protection of a state's land and maritime infrastructure, economy and environment from certain damages at sea. Experts and scholars in international relations say that maritime security can be divided into two types of soft and tight security.

\section{- Liberalism approach for maritime security}

The liberal view of maritime security is the regulation of maritime territory. Some legal experts interpret maritime security as a stable process in oceans subject to maritime law. Here, the projection of naval power to achieve common goals is also defined as a means of transforming traditional countries. The liberal approach offers a better logic than the realist approach and the creative approach.

\section{- The creative approach for maritime security}

This approach is an approach that explores the concepts of maritime security thought creative thinking, international relations, international interaction, and cognition, rather than referring to a list of threats and factors on maritime security. Professor Christian burger points out three concepts of maritime security, namely,

\section{The framework that protects}

02. The maritime security model

- Marine environment (include of Maritime security)

- Economic development (Include of Blue Economy)

- National security (Include of Sea power)

- Human security (Include of Human trafficking)

The world depends heavily on sea-borne trade for its continued existence and allowing all countries to participate in the global marketplace in the high seas. Undoubtedly, the economic and political affairs of South Asia have been dominated by the sea. Indian Ocean covers $20 \%$ of the earth and ranked in third largest water coverage of the world. Indian Ocean Region comprises 38 littoral states, 24 Ocean territories and 17 landlocked countries. Two adjoining seas connect with the Indian Ocean, the Arabian Sea and the Red sea, covering an area of $169,000 \mathrm{Sq}$. Miles through the striate of Babel Mandeb, and Persian Gulf, through the straits of Hormuz.

The Indian Ocean is possessed with vast natural resources, mineral, fish, marine products, oil resource and natural gas. It also provides a home to many choke points, such as the Straits of Hormuz, the Straits of Malacca, Lombok and the Sunda Straits. Any disruption in traffic flow through these points can have disastrous consequences. The disruption of energy flows in particular is a considerable security concern for littoral states, as the majority of their energy lifelines are sea based. Since energy is critical in influencing the geopolitical strategies of a nation, any turbulence in its supply has serious security consequences.

Sri Lanka's geographical location has, traditionally, represented a significant point in the Indian Ocean region. Since the ancient history, maintaining of a maritime domain became an important factor in Sri Lanka as it is an island nation and lies near to a regional superpower and also lies near the main sea route connecting West to East of world. Further, it is observed that two regional powers - China and India has made their presence in Sri Lanka in various methods such as ports, aviation and power plant constructions therefore it is paramount important to be aware of the maritime domain. It has enabled Sri Lanka to serve as a hub port to most of the countries around.

The powerful phenomenon of globalization has highlighted the criticality of Indian Ocean sea lanes for trade and energy 
security. Oil and gas- laden ships travel from the Persian Gulf transit via the Strait of Hormuz, around Sri Lanka through the Malacca Straits or Indonesia's archipelagic sea lanes into the waters of South China Sea. Reciprocal traffic, carrying finished goods comes from China, Japan, Korea and Taiwan the travels the other way. During the voyage they run the gauntlet of piracy, maritime terrorism and interstate conflict. This is what worries many nations whose economies are dependent on trade and energy.

The strategic location of Sri Lanka as well as the Indian Ocean was amply highlighted in a letter that was written by Admiral Raeder, the German C-in-C in a report to Hitler dated 13 February 1942, state; "Japan plans to protect this front in the Indian Ocean by capturing the key position of Ceylon, and she also plans to gain control of the sea in that area by means of superior naval forces. Fifteen Japanese submarines are at the moment operating in the Bay of Bengal, in the waters of Ceylon and in the straits on both sides of Sumatra and Java". "Once Japanese battleships, aircraft-carriers and submarines and the Japanese Air Force are based on Ceylon, Britain will be forced to resort to heavily escorted convoys if she desires to maintain communications with India and the Near East. Plans to strike westwards into the Indian Ocean and seize Ceylon had been prepared by the staff of the Japanese Combined Fleet".

\section{LITERATURE REVIEW}

Marine security research is scarce. But with respect to literature research, the marine safety research papers were reviewed as follows.

\section{Maritime issues between Indian Ocean and Sri Lanka}

"The one controlling the Indian Ocean is dominated Asia. This ocean is the key to the seven seas of the 21 st century, the destiny of the world will be determined in these waters." Alfred Thayer Mahan

The Indian Ocean region is the cradle of the sea floor was considered a playground of rich European industrial nations during the colonial era. With the start of decolonization in 1946, the euphoria of independence was overshadowed by the turbulence of internal conflicts and the ensuing interstate wars. During the Cold War, the two superpowers enhanced their maritime influence, directly or indirectly, with an impressive array of port facilities available in the region. The story repeated itself in a mature form.

\section{Piracy}

Piracy has become an issue for modern seafarers. The many reported and unreported incidents of piracy have raised considerable concerns and multinational efforts to deal with this violent threat. According to the 2002 Annual Report of the International and National Maritime Organization, the Straits of Malacca, the South China Sea and the Indian Ocean are the areas most affected by piracy. (International Maritime Organisation, "Reports on Acts of Piracy and Armed Robbery against Ships- Annual Report 2002”, 17 April 2003, available in pdf format at http//www.imi.org)

\section{Maritime Terrorism}

According to the admiral RC wijegunarathne, Maritime terrorism was active in the region and Indian waters in particular, since the mid-1980's due to the absence of an effective maritime safety mechanism. South Asia and its surrounding areas are the focus of terrorist activity, and links between terrorist groups are growing. Cross-border terrorism networks are active in the Middle East, Central Asia, South Asia and Southeast Asia. Amongst the few terrorist organizations that have acquired maritime capabilities, the Liberation Tigers of Tamil Eelam (LTTE) are the most effective group. The LTTE has been a pioneer in the development and broad use of suicide bombing as a terrorist weapon. The LTTE's military defeat and the dismantling of its military infrastructure have dramatically reduced security threats to South Asia. The LTTE has become a threat not only in Sri Lanka but also to other nations, because their techniques have been widely used and copied by other terrorist organizations. She had a close relationship with other terrorist groups that used her marine network. Pakistan and the Maldives experienced another type of maritime terrorist attacks the economic use of the sea coast by terrorists to gain access to the land asymmetric war against state actors. On 26 November 2008, a terrorist group shot and bombed India's financial capital, Mumbai, killing 164 people (26 of them foreigners). A group of Lashkar-e-Iba activists crossed the Arabian Sea through the Karachi Sea to a fishing village called Machchimaar Nagar in Mumbai. Later, the EU Home Secretary P. Chidambaram said in the LokSabha, "The Mumbai terrorist attacks have brought into sharp focus the vulnerability of our coastline that goes to $7,500 \mathrm{~km}$ and the imperative need to enhance maritime and coastal security".

\section{Drug Trafficking and Arms Smuggling}

According to Admiral RC Wijegunarathne, her research focuses on drug trafficking and arms trafficking is an important aspect of maritime safety. As a result of its enormous profits, the drug trade becomes one of the most profitable means of financing terrorist networks and arms trafficking. Due to Sri Lanka's proximity to 'Golden Triangle' and 'Golden Crescent', Sri Lanka had become a major transportation point for heroin to Europe and other Western nations on an organised scale. Heroin is shipped by sea through Sri Lanka from Pakistan or India on a large scale by containers and powered fishing boats. There are two kinds of shipping routes. Ace is from Pakistan to Mumbai (facilitated by underworld dons in the city), then to Tuticorin or Rameshwaram and then to Sri Lanka by sea, on from Pakistan to southern India.

\section{Human Trafficking}

According to Admiral RC wijegunarathne, his research is from a Sri Lankan point of view illegal migration is carried out primarily for economic reasons. With the annihilation of 
the LTTE on the dry ground in Sri Lanka, terrorists may also be illegally migrating encouraged by their foreign networks, and may also be rented in the trafficking of their cadres across borders. Sri Lanka's geographic location is also one of the closest factors to the rise of human trafficking. In the past, many illegally seeking asylum have used Thailand and Indonesia as transit points. But as we speak, things have changed. Sri Lanka was identified as a point of passage for the smugglers. The growing incidents of aliens using Sri Lanka to get on the ship number of locals taking the same risky route. In the last 10 to 12 months, the Sri Lankan navy has arrested over 2,000 illegal immigrants in Australia and a large number of fishing boats used. (Admiral RC wijegunarathn)

Literature review of the research showed that the future trajectory of maritime security in the Indian ocean is, strengthening cooperation on combating non-traditional threats as well as contentious issues like naval buildups and deployment of submarines. Increased interaction between IOR states to improve regional cooperation on maritime security threats. Security measures should be based on a robust prescriptive framework based on UNCLOS. Effectively combat non-traditional threats such as piracy by maintaining an ongoing naval presence in the Indian Ocean. Address development gaps that lead to vulnerable populations and maritime criminality. Increase information on IUU fishing, drugs and human trafficking.

\section{FINDING AND DISCUSSING}

The international security environment is dynamic and uncertain, with recurring disputes, crises, and struggles in many regions, and endemic conflicts in areas of special importance to the surety of the Sri Lanka. The safety of marine routes and bottlenecks is a concern that any maritime nation cannot ignore in the current scenario. The interdependence between nations for the good movement of world maritime trade cannot be denied, whose disruption will affect all countries and could be critical to some. For this cause it is predominant that the maritime community is set up to meet any contingency that may originate from these vital sea lanes, checkpoints and narrow seas coming under threat or siege. Unlike the past, current enemies are dynamic, erratic, networked and unorthodox. The safety of this ocean can be threatened by terrorist threats, national/state threats, transnational criminal threats and piracy, theft, etc. Illegal and unregulated fishing activities in these waters have become a major challenge not only for the safety of Sri Lanka but for other countries in the region.

\section{Maritime Security Challenges in the Indian Ocean and Non- traditional maritime security issues}

Maritime safety is one of the dying words of international relations. Major players have begun to include maritime security in their mandate or reframed their work in such conditions. Non-traditional security threats are seen as a new trend in security design. The Indian Ocean region has become a major energy and trade route in the world. The location of
Sri Lanka is also of great strategic importance. The Indian Ocean area faces numerous traditional and non-traditional safety and security challenges.

- The Indian Ocean area has strategic importance. This research has identified several ongoing issues in contemporary marine safety,

- The increasing militarization of the Indian ocean's strategic chokepoint

- The vast region of the Indian Ocean remains 'unpoliced', particularly the central Indian ocean.

- Maritime awareness (MDA) is lax

- Increasing freedom of navigation along the Indian Ocean's sea lanes of communication, whilst closing these lines to illegal actors.

Can be identified as the main factor.

also, traditional and non-traditional maritime security issues identified by studies in the Indian Ocean region as well as in Sri Lanka can be considered as, terrorism, human trafficking, irregular movement of a person, drugs trafficking in wildlife, trafficking of weapons, IUU fishing, degradation of ocean health, unlawful exploitation of marine resources and climate change, etc.

Terrorism and piracy can be highlighted as a major maritime security challenge in the Indian Ocean region. These factors indicate that the Indian Ocean region, which is strategically and centrally located, is Sri Lanka's most vulnerable coastal and ocean- centric location and a hub for international trade. Special attention is paid to the Indian Ocean as it forces on economic growth, foreign trade, and traditional security challenges. Emerging global trends in Sri Lanka are the impact of naval modernization. This can be seen as an emerging trend in border maritime security that deals primarily with piracy, terrorism, territorial disputes, and natural disasters. Also, a recent growing influence in the Indian Ocean is the tendency of Sri Lanka, also with global and regional powers such as china, the United States, and India, to pursue modernization to protect its territory. This is a curved soft power effect. There is also an increase in illegal fishing and human and drug trafficking in Sri Lanka. There, human trafficking can be traced back to the theft of kidneys and the rise of illegal immigration to Australia. Sri Lanka deals with its maritime security concerns, resource valuation, and mitigation of emergencies and challenges, and a growing lack of priority for investment processes. Sri Lankan by sea, victims of humans, weapons, and illicit trafficking are common. During the civil war with the L.T.T.E during the Sri Lanka civil war, the maritime tigers engaged in smuggling to finance internal operations.

However, despite the end of the war, during and human trafficking continued. There is also an increase in drug trafficking in Sri Lanka. Based on estimates and statistics, $95 \%$ of narcotics enter the country by sea. Furthermore, illegal and unregistered and illegal (IUU) fishing by local and foreign boats, problems inevitably associated with the movement of 
mechanized dollar vessels are causing critical ocean system damage and depletion of maritime resources. According to 2013 official statistics, $1.7 \%$ of Sri Lanka's GDP comes from the fishing industry (Blue Economy). Therefore, IUU fishing poses a serious threat to Sri Lanka's blue economy. And also as a developing country like Sri Lanka, the current debt and government fiscal deficit pose a serious challenge to the proper management of the maritime security threats and the modernization of the armed forces. IUU fishing threat also can be applied to the economy by the exploitation of resources, society by giving rise to social unrest due to the opening of fire by navies and the government's inability to stop illegal poaching, politics by exploiting the issue for political purposes, and the averment by using illegal and exploitative measures to catch fish. Military security is not escalated due to the asymmetric characteristics of India and Sri Lanka. Threats posed by illegal fishing activities have already been experienced by Indian Ocean and Sri Lanka so it is clear that the threat perception is not new. The dimensional analysis reveals that non-traditional threats associated with maritime terrorism have affected all sectors as indicated by Barry Buzan. The negative effects are transmitted from the bottom level (individual) to the highest level (International System) and do not consider boundaries.

01. Figure No 01: Maritime Security Challenges In The Indian Ocean Region

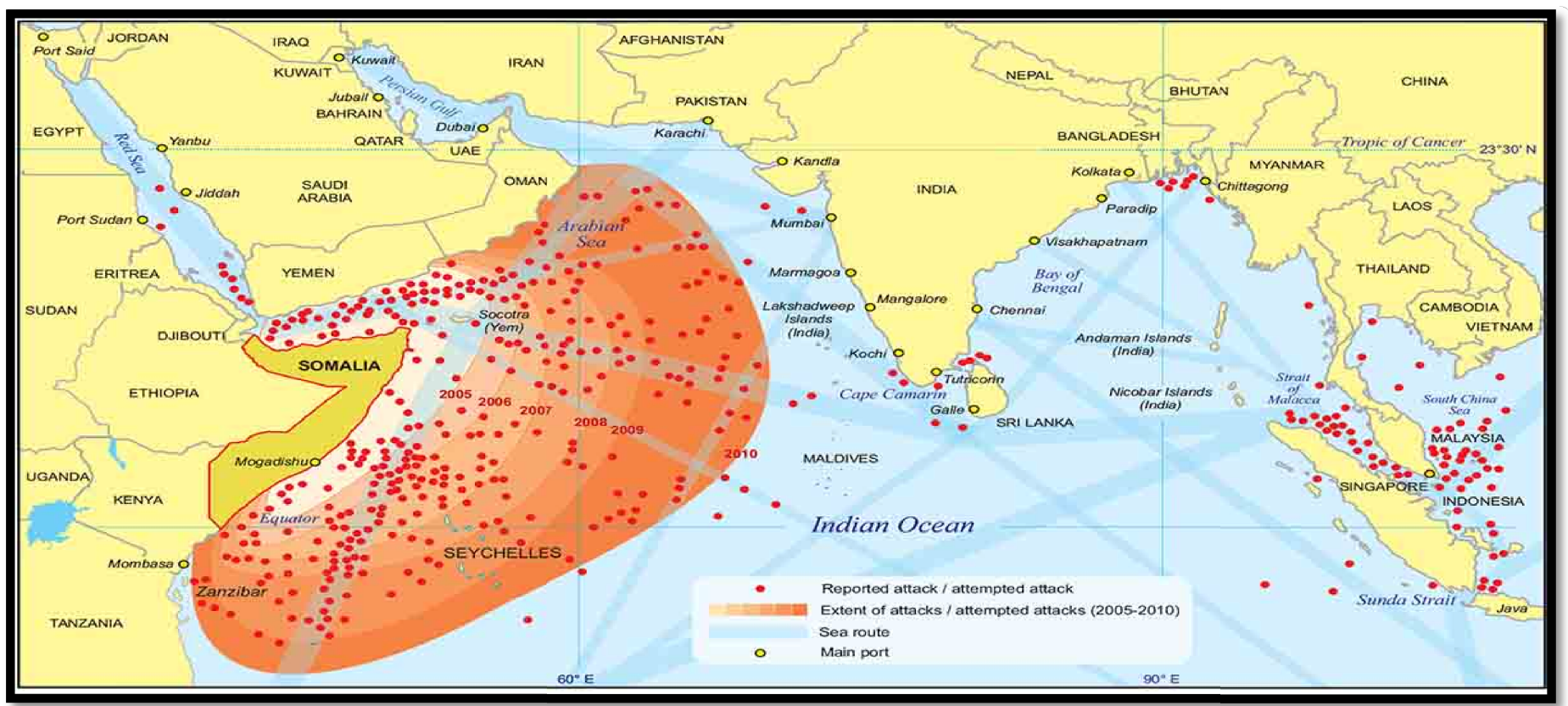

Source: https://thenewstoday.com.pk/wp-content/uploads/2020/05/Indian-Ocean-Security-Threats.jpg.

Contemporary Sri Lanka's approach to maritime security has had a significant impact on other state strategic environments. Sri Lanka's maritime security process has changed due to the dominance of Chinese activities in the Indian Ocean. The OBOR project, along with other perspectives on china's economic and geostrategic presence in the Indian Ocean, explores china's unprotected waters and deep seas and creates artificial islands. As a result, India is rapidly modernizing its navy and developing its existing competitiveness and strategic aggression capabilities with china. At the same time, chines loan assistance to ports in Sri Lanka and the lending of the port of Hambantota to china as a result of this inability to repay the loan has had an impact on Sri Lanka's maritime strategic security. This confirms the direct and indirect influence of soft power on maritime security.

IUU fishing, which poses a serious threat to Sri Lanka through the use of technological know-how, and technological knowhow and the use of strategies to control drug trafficking. Creating a quality navy is one of the major challenges facing Sri Lanka today. It is also possible to identify the impact of regional and international influence on Sri Lanka's maritime security and the impact on Sri Lanka's sovereignty and national security. As the hub of the Indian Ocean, Sri Lanka has made progress in strengthening its integration with regional power and economic integration. The role of the IORA in Sri Lanka's maritime security and defence process can be recognized as significant about regional security. Multilateral and bilateral security cooperation with Sri Lanka, China, and India is on the rise.

The Indian Ocean region is encompassed of some 2.6 billion inhabitants, making up to 40 percent of the overall world population and accounts for nearly 10 percent of global GDP. The littoral states of the Indian Ocean Region (IOR) have 80 percent of the world's proven oil reserves and some 17 percent of natural gas. In the 21 st century, the IOR is the world's largest trade route for long-haul cargo and vessel traffic. Approximately $33 \%$ of world trade and $50 \%$ of world container traffic originate from IOR trade routes. The Indian Ocean region is not just home to some of the most important maritime choke points of world commerce, including the most 
important Strait of Hormuz, Malacca and of Bab-el-Mandeb but also World's major oil shipping lanes are situated in the IOR. These bottlenecks are highly critical to world trade and energy flows, which is why many regional and extra-regional states have maintained their naval presence in the region. The coastal states of the IOR and extra-regional states are increasingly concerned about the safety of the communication channels of the energy sea.

\section{Maritime security in IOR:}

In the 21 st century, the IOR has become an epicentre of world politics, but because of the emergence of traditional and nontraditional security threats, the region has become less stable. The competition among regional and extra-regional states to increase their area of influence in the IOR as well as the emergence of non-traditional security threats have exaggerated the security office in the area. The restrictions of the regimes in their mental ability to deal with maritime domain along with the changing regional security situation has resulted in the growth of unlawful actions in the Indian Ocean area. Threats to maritime security include piracy, trafficking in people, drug trafficking, terrorism and other non-traditional security threats. Due to these threats, marine safety interaction has increased between national navies. Ensuring safety at sea has been a major challenge for existing marine forces. The challenges and threats in the Indian Ocean region are both traditional and unconventional. To deal with these threats and challenges in the maritime field, the role of regional and extra-regional States are of immense importance. As the economic activities are extending in the maritime sphere, the states cannot neglect the threat of maritime terrorism, piracy, maritime pollution, illegal fishing, and irregular migration through the ocean, small arms trafficking, illegal narcotic and human trafficking through the seas. Another major issue in the RON is illegal, unreported and unregulated (IUU) fishing. IUU fishing not only depletes fishing, but also fuels the perpetuation of illegal migration, marine, terrorism and human trafficking at sea. In the 21st century, no state can cope with these security threats because it requires a naval capability that no state currently possesses. Multilateral collaboration is therefore necessary for maritime safety in any region. Working together among stakeholders is the most appropriate way to address these overwhelming challenges. The collaboration among the like-minded states will ultimately cut the load on an individual body politic as it would ensure security and refuge at the maritime domain by promoting trust among the countries. The nature of security threats has shifted considerably.

In the maritime sector, threats are non-traditional, multifaceted in nature, and multi-directionality has made it more difficult for states to anticipate and assess these threats. Therefore, to counter such threats within the IOR, a collaborative security mechanism is required.

Maritime Terrorism
Maritime terrorism has been active in the region and in Indian waters, especially since the mid-1980s due to the absence of an effective maritime security mechanism. South Asia and its surrounding areas are the hub of terrorist activity, and there is increased connectivity between terrorist groups. Trans-border terrorist networks operate in the Middle East, Central Asia, South Asia and Southeast Asia. Among the few terrorist organizations that have acquired maritime capabilities, the Liberation Tigers of Tamil Elam (LTTE) where the most efficient group. The LTTE has taken a pioneering role in the development and widespread use of suicide bombing as a terrorist weapon. The military defeat of the LTTE and the dismantlement of its military infrastructure have significantly reduced security threats in South Asia. The LTTE has become a threat not only in Sri Lanka but to other countries as well, because their techniques have been extensively used and copied by other terrorist organizations. It had strong ties to other terrorist groups that used its marine network. Pakistan and the Maldives experienced another type of maritime terrorist attacks the economic consumption of the sea coast by terrorists to acquire admission to the land asymmetric war against state workers. On November 26, 2008, a group of terrorists launched a series of shooting and bomb attacks across Mumbai, India's financial capital, killing 164 people (including 26 foreigners). A group of activists from Lashkare-Iab, who came from Karachi through the Arabian Sea, arrived in a fishing village called Machchimaar Nagar in Mumbai.

\section{Drug Trafficking and Arms Smuggling}

Drug trafficking and arms trafficking are significant aspects of maritime safety. Due to huge profits, drug trafficking has become one of the most money-spinning means, which is applied to finance terror networks and arms trafficking. Due to Sri Lanka's proximity to 'Golden Triangle' and 'Golden Crescent', Sri Lanka had become a major shipping point for heroin to Europe and other Western countries on an organised scale. Heroin is shipped by sea through Sri Lanka from Pakistan or India on a large scale by containers and mechanized fishing vessels. There are two forms to this marine route. Ace is from Pakistan to Mumbai (facilitated by underworld dons in the city), then to Tuticorin or Rameshwaram and then to Sri Lanka by sea, on from Pakistan to southern India.

The trafficking of weapons by sea is also the most secure means for the transfer of weapons and ammunition throughout the world. Arms smuggling can cause conflict or interstate conflict. The relationship between drug traffickers and weapons traffickers is well known around the world. Nationally, drug trafficking and arms trafficking can affect government. Furthermore, small arms smuggling can involve the local government, including the military takeover of the civilian government, as we have seen recently in countries in the region. Reversing the drug trade and arms smuggling is one of the security challenges facing Sri Lanka. 
Recent security reports indicate that smuggling, narcotics and human trafficking activities occur across the maritime borders between India and Sri Lanka. According to media reports fishermen and some who pose as fishermen from across the Palk Strait were not merely engaged in poaching, but also in drug trafficking, thereby becoming the Northern region into a hub for drugs. The passage through Palk Sound is the most practical route for smugglers operating between the two countries. Previously, smugglers smuggled textiles and gold from India on boats. But in recent times, the cargo has changed and the Strait of Palk is used to import drugs and for human trafficking. Sri Lanka's Minister of Law and Order, Sagala Rathnayake, told Reuters that Sri Lanka is now a gateway for major drug traffickers. Coming up to the UN Security Council Aria Formula meeting, he had further mentioned that "The role of the Indian Ocean as a major drug trafficking highway, particularly for heroin originating in Afghanistan, poses a threat to maritime security and calls for a maritime law enforcement change". The United Nations Office on Drugs and Crime (2005) pointed out that India routinely reports the trafficking of heroin on a heavy shell from the Southern part of that country into Sri Lanka via the Palk Strait. The president of the National Dangerous Drugs Control Board said drug trafficking by sea routes has increased in recent times (Jayamanne, 2016). The Central Bureau of Narcotics, India, reported that heroin seizures in the Indo-Lankan sector were up 6\% (UNOCI, 2005). In recent times, the Sri Lankan navy has seized a great deal of cannabis from the North Seas. Colombo Page reported that a withdrawal of naval personnel from the Northern Naval Command while patrolling in the sea off Veththalakerni in the North nabbed two suspects with $79.3 \mathrm{~kg}$ of Kerala cannabis. Because of drug smuggling activities in the Indian Ocean, Sri Lanka has recently become a focal point for narcotics.

\section{Maritime piracy}

Since 2007, maritime piracy has become a significant impediment to world maritime trade. The estimated annual cost of piracy for the world economy is between $\$ 7$ billion and $\$ 12$ billion. The expected cost of piracy in 2014 is $\$ 13$ to $\$ 15$ billion. In 2010, 86 per cent of global piracy activity was committed by Somali pirates. Numbers declined marginally in 2011 , but remained alarming at $62 \%$. According to the International Chamber of Commerce (ICC), there were 439 pirate attacks worldwide in 2011 and up until mid-September of this year there were 225 . The instability in the interior of Somalia has transcended the high seas, including India's west coast and the south as the channel of Mozambique. Maritime piracy is an anticipated safety challenge for Sri Lanka. While there have been no reports of piracy in Sri Lankan waters, there have been numerous incidents in the Indian Ocean. Currently, there is no direct impact on Sri Lanka, but this affects global maritime trade and, as a result, Sri Lanka may be affected as well. The Dondra's traffic separation system may have a minor piracy risk. A Somali sailor who arrested Dondra Head Sea sped up the imagination and fear of piracy in Sri Lankan waters.

\section{Unreported and non-regulated illegal fishing}

There have been problems with non-reported illegal and unregulated fishing activities across the EEZ of the country. These include, but are not limited to, bottom trawling, the use of illegal fishing nets and the use of explosives and poisons, etc. It is the navy's responsibility to protect the nation's fishery resources. The sharing of fisheries resources with neighbouring countries, at the moment, the intrusion of Indian trawler fishermen in Sri Lankan waters is a huge challenge to the navy. Eradicating terrorism in the country has provided more flexibility for fishing in territorial waters. Sri Lanka should be capitalized in this regard and dominate the northern waters that have been enriched by the richness of fisheries. The Sri Lankan navy is expected to contribute more to fishing safety, which will solve the problem of trans boundary fishing over the years.

\section{Human Trafficking}

Human trafficking is also reported in the Indian Ocean recently, with a number of reported cases of illegal migrant parties in Malaysia, Indonesia and Australia via the sea. There is a steady stream of illegal migrants from Sri Lanka trying to visit Australia, even risking their lives. Groups of human trafficking organizers are transporting refugee claimants to Australia on dangerous journeys on dilapidated ships simply to make money. Some unfortunate incidents like sinking of ships have taken place and a number of lives lost of people from developing countries. As an example, 225 persons drowned near Christmas Island in 2010 while travelling illegally to Australia. Operation Sovereign Borders Commander Craig Furini reports that over 1,200 people drowned at sea while attempting to make such illegal and dangerous trips (Gamage, 2019). Conscious of the dangers of these voyages, the Government of Sri Lanka has sought to control this illegal activity within the Sri Lankan maritime zone. Public awareness programs have been implemented by the Sri Lankan government with the assistance of the Australian Customs and Border Protection Service to address these illegal marine activities (Karunarathna, 2013).

During the civil war, the LTTE and other activist organizations regularly crossed the maritime border between India and Sri Lanka to carry their soldiers and weapons in secret. Coastal regions of northern, northwestern and northeastern Sri Lanka have also witnessed numerous movements of activists who have carried their goods from southern India. In addition, the military activities of the "Sea Tigers" that used to organize naval attacks against Sri Lankan security forces were also in full swing in those areas. During the period of armed conflict the Sri Lankan Navy was highly active along the maritime boundary between India and Sri Lanka as one of its commissions was to protect it.

\section{Developing Seaports in the Indian Ocean Region}

Ports and navigation are important for the economic development of Sri Lanka. The strategic geographic location of Sri Lanka for trade, transport and transhipment activities 
creates great potential to consolidate its position as a naval and aeronautical centre of Asia. In order to accelerate activities in the development of port infrastructure, several mega port development projects have already been initiated during the period 2006-2010, including the Colombo South Harbour project and the port of Hambantota.

\section{Port of Vallearpadam in Kochi}

Vallarpadam Terminal is the largest single container terminal operator in India and the first in the country to operate in a special economic area. The terminal makes Kochi a key hub in the shipping world, reducing India's dependency on foreign ports for managing transhipment. This includes the decision to accelerate the exemption process under the Coasting Trade Act at the International Container Transfer Terminal (ICTT). The cabotage rules stipulate that only Indian supply vessels can carry goods from one Indian port to another. Mother vessels were getting these rules as disincentive to come to Vallarpadam and they opted for ports like Colombo as they can re-send the freight from there in foreign flagged vessels even to Indian ports. Currently, the Coasting Trade Act does not permit a foreign-flagged vessel to carry import cargo between Indian ports that have been carried on the same shipping line. The law does not even allow the transfer of empty containers between Indian ports on a foreign-flagged line. This affects the concept of "just-in-time logistics" to such an extent that it raises the cost of the end product and adds to the associated infrastructure. Allowing transhipping export-import cargo at Indian ports would also place a lot less pressure on the route and rail transportation in India, therefore setting aside for lower emissions and more efficient transit. Relaxing the cabotage law and making the port tariff competitive with nearby foreign ports would help in getting more mainline vessels calling India, as it will provide better parcel sizes and economic systems of scale.

\section{Colombo Port Extension Project}

The Sri Lankan port industry is dominated by the port of Colombo. It is the only port equipped to handle container traffic, and manages $95 \%$ of Sri Lanka's global trade. It also serves as a transhipment port for South Asia; $70 \%$ of Colombo's container volume consists of transhipment traffic to and from the Indian sub-mainland (ISC). The mass of containers handled increased from 200,000 twenty foot equivalent units (TEU) in 1985 to 1 million TEU in 1995, but the growth rate then tapered off and stagnated between 1997 and 2000 with an annual norm of 1.7 million TEU. The growth went up, and in 2006 Colombo Port managed 3.08 million TEUs. Unmatchable of the primary causes for the stagnation and slow growth in growth is Colombo Port's lack of competitiveness with other major transhipment ports established to provide for Indian subcontinent traffic. The employment of larger container ships means that Colombo Port now has to compete with established ports such as Singapore and new ports such as, Dubai, Port Klang, Salalah and TanjungPelepas in the Indian Subcontinent transhipment market. These ports are owned in whole or in part by existing port operators and shipping companies, and are capable of providing higher productivity and faster turnaround times. They therefore have an inherent advantage in competing for the Indian subcontinent market. Colombo Port's efficiency and locational edge in the Indian Subcontinent transhipment market has so eroded as new musicians in South East Asia and the Gulf region have used more modern institutional structures and equipment to reduce ship waiting and turnaround times.

Colombo Port is unable to offer the additional operating capacity necessary to compete in the Indian market of transhipment subcontinent Colombo Port has a depth of 15 meters $(\mathrm{m})$. That means they can't dock the next-generation container ships, which is, 9,000 TEU vessels; its competitors in Dubai, Singapore, Salalah, and TanjungPelepas can all berth 9,000 TEU vessels. In economic terms, container ships are increasingly numerous. Major shipping lines have already launched 11,000 TEU vessels for the Asia-Europe route, and in the succeeding 10 years major container lines could possibly deploy vessels with 13,000 TEU carrying capacity. All hub ports need to modernize their infrastructure in order to accommodate these larger vessels or to see their competitive position eroded.

The expansion of Colombo's port capacity is designed to assist exporters, importers and value-added service providers by potentially contributing more to gross domestic product (GDP). The expansion project of the south harbour will more than replicate the capacitance of the Port of Colombo in container handling services and will induce a positive impact on the export/import and value adding service industry and also to the south Asian shippers at large with more efficient transhipment services and connectivity.

The proposed Colombo South Harbour will be located west of the existing southwest breakwater within an area of approximately 600 hectares. The proposed harbour will have 4 terminals of over $1,200 \mathrm{~m}$ in length each to accommodate 3 berths alongside depths of $18 \mathrm{~m}$ and provision to deepen to $23 \mathrm{~m}$ to accommodate deeper draft vessels of the hereafter. The width of the harbour channel is $560 \mathrm{~m}$ and the depth $20 \mathrm{~m}$, with the depth of the harbour basin of $18 \mathrm{~m}$ and a revolving circle of $600 \mathrm{~m}$. The project will benefit Sri Lankan exporters by improving their competitiveness on international markets through lower transport costs and shorter delivery times for time-sensitive exports (e.g., Textiles, which represent 52 percent of Sri Lanka's exports. Lower transportation costs are expected to translate into annual savings of $\$ 82$ million by 2015 , with shorter delivery times leading to annual savings of $\$ 49$ million by 2015. In addition, translate traffic will generate $\$ 77$ million in direct net annual revenue to terminal operators by 2015 . The Project will help consolidate the situation of the Colombo Port as a transhipment hub port for the South Asian region by providing sufficient container handling capability and sufficient depth for the latest generation of mainline vessels to call at Colombo Port. Each terminal will have a handling capacity of 2.4 million TEU/year. When three 
terminals are fully developed, they will provide additional capacity of 7.2 million TEUs per year. Maintaining its status as a transhipment centre will help enhance domestic competitiveness in international trade by reducing costs and accelerating delivery, as well as generating additional revenues through transhipment. Consideration of SLPA's approach to providing infrastructure (breakwaters, canals, etc.) Which can accommodate three terminals, economic and financial analyses are based on the scenario that three terminals will be developed sequentially as required to meet projected demand.

\section{Hambantota Harbour}

Hambantota is located within 10 nautical miles of the busiest seaway in the world, and is ideally located directly across the main international maritime trade routes. Complete 100 ships bypass Sri Lanka daily during the voyage between Europe and far east, necessitating the carrying a large amount of fuel and supplies for the journey, which could be replaced by cargo if servicing is provided midway at Hambantota. Hambantota is destined to become Sri Lanka's main seaport, surpassing Colombo. This is the world's first shore-constructed port.

\section{Sri Lanka's Approach to Overcoming Challenges}

The greatest challenge in the area right now is diplomacy. The role of the Sri Lanka Navy in actively engaging in maritime operations in collaboration with other interested countries without antagonizing their national interests is a tremendous challenge to the Navy. The Sri Lanka Navy should focus on maintaining progressive and positive relations with all stakeholders in maritime operations linear concern with our national interests.

02. Figure No 02: Map of Maritime zones in Sri Lanka

\section{Map showing the Maritime Zones of Sri Lanka}

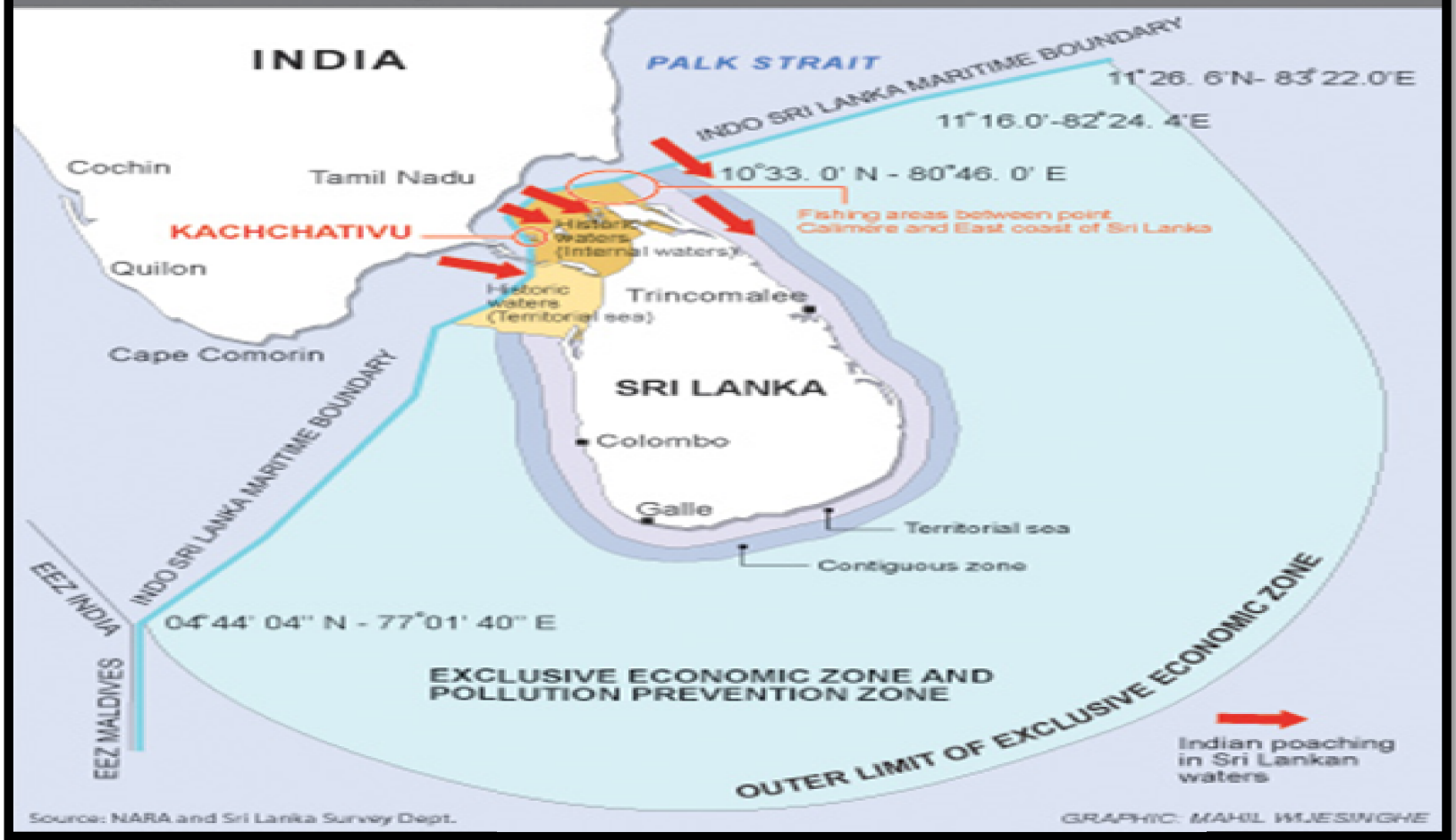

Source: http://www.sundayobserver.lk/sites/default/files/news/2016/11/12/z_p04-Depriving-03.jpg

The emerging strategic environment in the Indian Ocean region and the role of the Sri Lankan Navy, represent a significant challenge to the Navy. As mentioned earlier, Sri Lanka has a greater obligation to prevent piracy, weapons smuggling, criminal activity and terrorism within the exclusive economic zone and beyond. The navy should be able to support the international mechanisms that exist at sea in this respect. The greatest challenge facing the Navy is the protection of marine communication channels and ports against these emerging threats. Improving surveillance in the $\mathrm{AOR}$ and beyond is what we are looking for.
The protection of the immense body of water towards the south of the island is an enormous challenge for the Navy. The obligation lies with the Extended Search and Rescue Region and the efficient operation of the Maritime Rescue Coordination Centre (MCRC) is a huge global responsibility that rests on our shoulders. Improving the capabilities of the Global Maritime Distress and Safety System (GMDSS) is also an important challenge and an obligation for us.

Sri Lanka has a strong maritime heritage. Protecting marine heritage from treasure hunters is also an enormous responsibility in our field of action. It is hard to preserve these 
interests in the international community. Protecting the coastline's bio economic environment safely also has a direct impact on ocean operations.

Sri Lanka has had the chance to discover oil resources in the Indian Ocean region, especially in the Mannar Basin, which could host new economic opportunities in the future. Currently, there have been no targeted studies of gas hydrate potentials of the Sri Lankan coastline. The complexity of the
Strategic environment is merely offering a large opportunity for the Navy to have co-ordinate maritime operations with the other maritime nations regionally and beyond specially with Indian, Unites States, United Kingdom and China whose having great business to the region. Sri Lanka is expected to assist these countries in conducting maritime operations in close proximity, providing greater development opportunities.

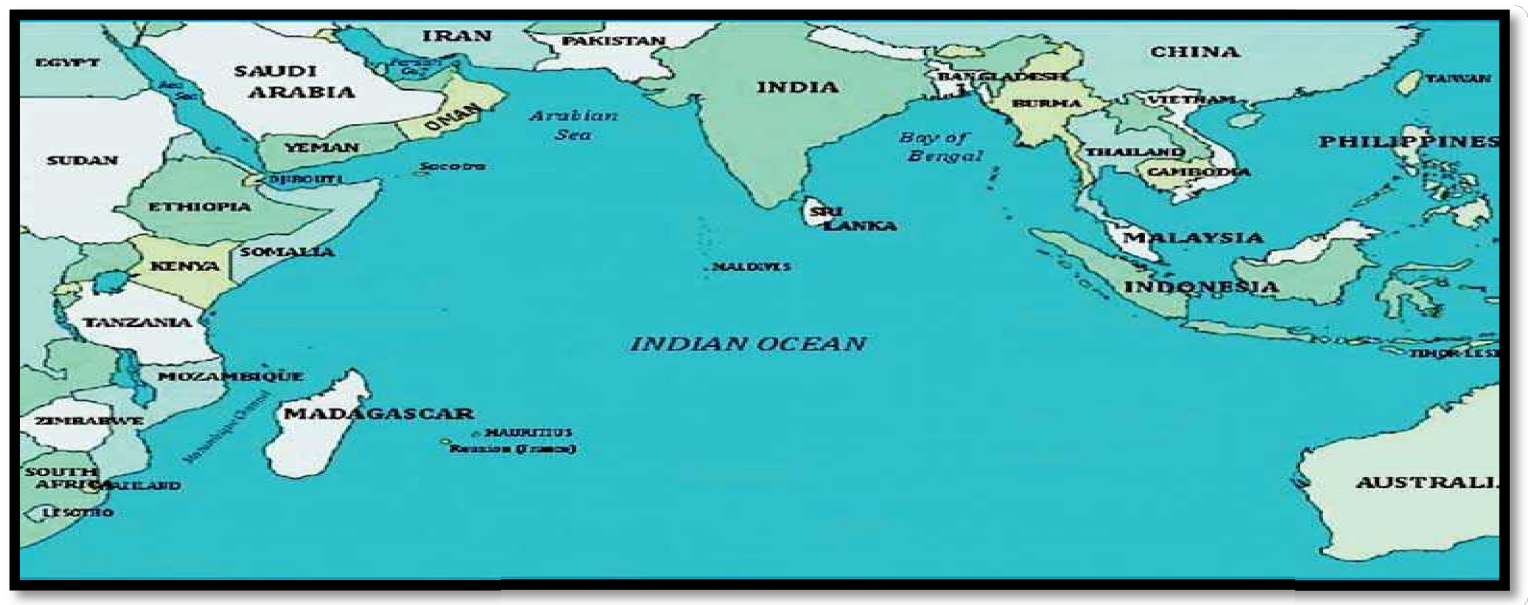

Source 01: https://www.google.com/url?sa=i\&url=http\%3A\%2F\%2Fwww.ft.lk\%2Fshippingaviation\%FI identifying-future-maritime-challenges-A-Sri-Lankan perspective\%2F21685977\&psig=AOvVaw2abfNo99L4aF_t6so oY8y\&ust=1609999495884000\&source=images\&cd=vfe\&ved=0CAIQjRxqFwoTCOjv19b hu4CFQAAAAAdAAAAABAD

Source 02: Admiral Jayantha Perera (Thursday, 19 September 2019 00:13) Identifying future maritime challenges: A Sri Lankan perspective.

Security challenges require greater accountability in protecting trade and energy in the region. Safety crews on board are something the Sri Lankan navy is doing right now. This requirement of security encourages us to have collaborative efforts, joint practice sessions, joint operations, sharing of resources, expose to new technology and most importantly, this gives opportunity to expose our Navy to the cosmos so that our Officers and sailors can gain professional competency.

The surety of their own economy in terms of energy and the business deal via the sea lanes and shipping is the greatest worry of all the nations provides greater opportunities for the Sri Lanka Navy to win many a benefits ensuring security of all the shipping in our arena of duty. The unearthly and unprecedented emerging threats of the sea require intelligent sharing among nations. It's really important for the Navy to be impersonal and impartial in order to cooperate with other countries to attend as a nerve centre of disseminating news to all the stakeholders will enhance the Navy's credibility been amidst. With the eradication of the country's terrorism, offers more room for manoeuvre for fishing in our waters. Sri Lanka should be capitalized in this regard and dominate the northern waters that have been enriched by the richness of fisheries. The Sri Lankan navy is expected to contribute more to fishing safety, which will solve the problem of trans boundary fishing over the years. Great amount of merchant ships transiting across provides opportunities to take charge the violations of international laws and breaks of local laws widely with regard to the customs and sanitary law's in the nation. The Sri Lankan navy is expected to play an active role in this respect. We should ensure that shipping respects the legal conduct we impose on them through our local legislative assembly. This would ensure the safety and security of national waters and improve the reputation of nations as maritime nations.

\section{Trespassing On Maritime Borders and Poaching In Sri Lankan Waters.}

One of the burning maritime problems facing Sri Lanka has been illegal poaching by fishers in both countries in recent decades. As mentioned earlier, prior to 1976, anglers from both countries fished in Palk Bay without barriers. With the signing of the Sea Border Agreement in 1976, Indian fishermen have lost their fishing rights since Sri Lanka acquired sovereign rights to the continental shelf and the EEZ. As a result, Indian fishermen were prohibited from breaching the marine border in order to catch fish in Sri Lankan waters. Notwithstanding the agreements, fishermen in both countries have a history of violating their respective maritime zones and poaching in these waters over the past few decades. During the civil war, the Sri Lankan government banned all fishing in the North Seas as a result of the current security situation. The government took this step because LTTE members disguised themselves as fishermen and transported ammunition and their frames through Palk Bay and the North Sea. However, after 
the end of the war in 2009, illegal poaching was resumed and practised principally by Indian fishermen. There are two aspects of this important issue. First, because of poaching by Indian fishers, Sri Lanka continues to lose a significant amount of fish annually. Annual catches of fish by Indian trawlers in Sri Lankan waters are estimated to be approximately 1557.7 metric tons (Hettiarrachchi 2007). President of the Sri Lanka Seafood Exporters Association has said that the deprivation made by the poaching Indian fishermen has been calculated to be over US\$ 750 million annually (Hettiarrachchi, 2007). The Palk Bay continues rich in Tuna and Prawns and Indian fishermen to take hold of practically the total fish harvest while the Sri Lankan fishermen suffer severe loss of their support. According to reports, over 100,000 families make their living from fishing in the Northern Province (Krishnaswamy, 2014).

In addition, it has been reported that Indian fishers are using new and illegal methods to capture fish in this area. According to these reports, Indian fishermen use vessels 24 to 46 feet long equipped with internal engines and bottom trawling techniques (Hettiarrachchi 2007). As fishers use these types of trawlers, they harvest a huge harvest while damaging the fishing nets laid by local fishers. Furthermore, these methods are turning out to be a great threat to the maritime resources of Sri Lanka because this type of mass scale fishing by Indian trawlers completely strips the seabed of all kinds of life including the rising fish and other beings. Fishers in Sri Lanka complain that Indians use fishing methods that devastate marine resources and destroy the fragile ecosystem. This method, referred to as "pair trawling", involves two boats using drag nets that sweep the ocean floor clean, with dramatic consequences (Kurukulasuriya 2012). The ability to regenerate is seriously compromised. Therefore, it has a serious impact on the fishery going forward. Consequently, illegal poaching by Indian fishermen has had a serious impact on the country's economy and the marine environment.

Another aspect of that is the impact on the security of both countries. The maritime guard forces of Sri Lanka (Sri Lanka Navy) perform patrols to protect Sri Lanka's maritime borders in Palk Bay and the Gulf of Mannar. As the Navy has moved up the "security zone" in the Northern Sea in the post-war period, there is an increased potential for illegal poaching in the Northern waters by Indian fishermen who hold no qualms about violating the maritime boundary between the two nations. In South India, there are over 5,000 trawlers and close to 2,500 depend on Sri Lankan waters for their catch (Madanayake, 2015).

The Navy often fires or stops Indian fishing vessels that cross marine boundaries and encroach on Sri Lankan waters. The border protection activities of the Sri Lanka Navy have resulted in a substantial number of Indian fishermen being held in the last decade because they entered Sri Lankan waters and absorbed in fishing activities. This led to diplomatic clashes between India and Sri Lanka. Most often, the Tamil Nadu government blames the Sri Lankan government for claiming that the arrested Indian fishermen are being tortured and harassed by the Sri Lankan navy. The Tamil Nadu state government is using that strategy to embarrass the Sri Lankan government internationally. The Sri Lankan government responded that it had taken steps to release most of the arrested fishermen and their vessels as a humanitarian gesture. As well, the Indian government has also arrested a number of Sri Lankan fishermen who have breached the Indian maritime border over the past two decades. In general, there are a number of complaints about the apprehension of fishermen by both parties when their territorial waters are breached by nonnationals. Sometimes the off ending fishermen have been jailed for weeks, months and in some cases even for more than a year, until their respective governments intervene to get them released (Kurukulasuriya, 2012). It is worth noting here that both governments have agreed to find a permanent solution to this issue very soon. For instance, several treatments have been taken out at ministerial level by the two governments, but even they have not been capable to get a lasting answer to the problem of illegal poaching in the Palk Bay and the Gulf of Mannar.

\section{CONCLUSION}

According to the research, many maritime security issues can be identified in the Indian Ocean and Sri Lanka. There is a growing trend of international and non- traditional challenges. The impact of soft power has been ever greater and represents a major maritime challenge. The maritime frontiers between India and Sri Lanka were clearly defined in 1974 and 1976 as part of the agreement signed by the two countries. But it is clear that the waters of Palk Bay and the Gulf of Mannar continue to create tensions between the two countries. The matter of Katchatheevu Island also continues to create diplomatic tensions between Sri Lanka and India on occasion. This is because this subject plays an important role in the people's policy of Tamil Nadu in South India. Illegal poaching causes problems in both countries due to security impacts and arrests of fishermen found on the wrong side of the marine border. In addition, Sri Lanka is severely affected, both economically and environmentally, in the long run as a result of illegal fishing activities. Therefore, both governments should take strong action to avoid border violations and poaching by their fishermen in the marine waters of their neighbours. The Strait of Palk has now become a popular transit point for heroin traffickers in the area. The threat of narcotics continues to be linked to terrorism and other human trafficking activities in the region. Consequently, Sri Lanka's national security will be severely affected if the authorities fail to take corrective action soon. To achieve effective outcomes, it was noted that the Sri Lankan government should work with the Indian government to address these issues. Diplomatic and political relations between the two countries will be considerably improved if mutual cooperation can be organised. And also the Indian Ocean region needs to take a more structured and holistic approach to address global and regional topics, holding into account security challenges posed by enemy civilians and pirates at sea and by various 
sources, including NGOs such as armed pirates. It requires long-term strategies not only to modernize, update and strengthen the navy, but also to address gaps in decisions- and policies. Defence is needed in the Indian Ocean call on the US to pursue a long-term maritime security policy in close strategic cooperation with major powers like Japan and Australia.

\section{REFERENCES}

[1] Angel, T.M (2008). Toward a maritime strategy. In P. Taylor (Eds), perspectives on maritime strategy- essays from the Americas, Rhode Island; naval war college press.

[2] Alani, M (2009). Toward a comprehensive maritime security arrangement in the gulf. In E. Laipson and A. Pandya (Eds) The Indian Ocean: resource and governance challenges (PP.34-3). STIMSON.

[3] Akimoto, K (2001). The current state of maritime securitystructural weaknesses and threats in the sea lanes. Conference on maritime security in Southeast Asia and southwest Asia, institute for international policy studies.

[4] Axelrod, R. And Hamilton, W.D. (1981). The evolution of cooperation. Science, 211 (4489), 1390-1396.

[5] Axelrod, R (2000). On six advance in co-operation theory. Analyse and Kritik 22, 130-151.

[6] Arsenault, C (2014). "Only 60 Years of Farming Left If Soil Degradation Continues", Scientific American, Retrieved 2017-1217.

[7] BA, A. (2006). Who's socializing whom? Complex engagement in sino-Asian relations, the pacific review, 19 (2), 157-179.

[8] Balachandran, S. (1995). Shorebirds of the marine national park in the Gulf of Mannar, Tamil Nadu. Journal of the Bombay natural history society, 92,303-313.

[9] Balaresque. J, Manzano, and fontena, H. (2008). A new U.S. Maritime strategy for the twenty-first century viewed from an institutional perspective In P. Taylor (Eds.), Perspectives on maritime strategy. Newport. RI: Naval war college press.

[10] Bueger, Christian; Edmunds, Timothy (November 2017). "Beyond seablindness: a new agenda for maritime security studies", International Affairs. 93 (6): 1293-1311. doi:10.1093/ia/iix174.

[11] Bueger, Christian (March 2015). "What is maritime security?" Marine Policy. 53: 159-164. doi:10.1016/j.marpol.2014.12.005.

[12] Bueger, Christian; Edmunds, Timothy (November 2017). "Beyond sea blindness: a new agenda for maritime security studies", International Affairs 93 (6): 1295.

[13] FCNL (2015). "Peace through Shared Security" Retrieved 201712-17.
[14] General Sir Nicholas Houghton (2015). "Building a British military fit for future challenges rather than past conflicts", Www.gov.uk. Retrieved 2017-12-17.

[15] "ISO 28007 (2015). Guidelines for Private Maritime Security Companies (PMSC) providing privately contracted armed security personnel (PCASP) on board ships (and pro formal contract)", International Standards Organization. 2020-07-17.

[16] Jump up to a b Barry Buzan, Ole Waver, and Jaap de Wilde, (1998). Security: A New Framework for Analysis (Boulder: Lynne Rienner Publishers, p. 32

[17] Jump up to a b c d Gee, D (2016) "Rethinking Security: A discussion paper"(PDF). Rethinkingsecurity.org.uk. Ammerdown Group. Retrieved 2017-12-17.

[18] Klein, Natalie (2011). Maritime Security and the Law of the Sea, Oxford University Press, p. 11. ISBN 9780199566532.

[19] Krishnaswamy, P (2014). Northern fishers still in a quandary, No solutions in sight, Sunday Observer, 13.07.2014.

[20] Lars H. Bergqvist (2014). "The ISPS-Code and Maritime Terrorism", Centre for International Maritime Security.

[21] Madanayake, S.A (2015). Illegal fishing issues as a non traditional security threat to Sri Lanka - with reference to India, Proceedings of 8th International Research Conference, Kothalawala Defence University, Sri Lanka.

[22] Manoharan, N (2013). Beijing and India-Sri Lanka relations, Issue \#217, IPCS. Downloaded from: http://www.ipcs.org

[23] Perera, Y (2018). Kachchaateevu and an Island that promises peace and reconciliation, Downloaded from: http://www.dailymirror.lk

[24] Rajakaruna, L (2017). Indian Supreme court clears the catch 'KACT' Downloaded from http://www.mfa.gov.lk/ta5117-inqkacha/

[25] Rogers, P (2010). Losing control: global security in the twentyfirst century (3rd Ed.) London: Pluto Press. ISBN 9780745329376. OCLC 658007519.

[26] The alpawila, O.N. (2014). India-Sri Lanka relations: In post-civil war in Sri Lanka, International Journal of Social Sciences, Vol.2 Issue 01, pp. 9-14.

[27] US, Department of Defence (2000). "Joint Vision 2020 Emphasizes Full-spectrum Dominance", Archive.defense.gov. Retrieved 2017-12-17.

[28] United Nations General Assembly (2010). "Resolution adopted by the General Assembly on 20 December 2010," Www.un.org. Retrieved 2017-12-17.

[29] United Nations. (2017). "UN Trust Fund for Human Security". www.un.org.

[30] United Nations General Assembly (2005). "Resolution adopted by the General Assembly 60/1: World Summit Outcome" (PDF). Retrieved 2017-12-17. 